\title{
Demonstration of choreic movements in a case of chorea gravidarum
}

\author{
Monika Pathania, ${ }^{1}$ Bhagat Singh Lali, ${ }^{2}$ Neeraj Kumar Yadav, ${ }^{2}$ Aditi Chaturvedi ${ }^{3}$
}

${ }^{1}$ Department of Internal Medicine, VCSG Government Medical Sciences and Research Institute, Srinagar (Garhwal), Uttarakhand, India ${ }^{2}$ VCSG Government Medical Sciences and Research Institute, Srinagar (Garhwal), Uttarakhand, India ${ }^{3}$ Department of Pharmacology, VCSG Government Medical Sciences and Research Institute, Srinagar (Garhwal), Uttarakhand, India

\section{Correspondence to} Bhagat Singh Lali, lali_dreams@yahoo.com

\footnotetext{
To cite: Pathania $\mathrm{M}$, Lali BS, Yadav NK, et al. BMJ Case Rep Published online: [please include Day Month Year] doi:10.1136/ bcr-2012-008234
}

\section{DESCRIPTION}

This case is discussed at this platform mainly to share the video demonstrating the choreic movements in a case of chorea gravidarum. A 21-year-old primigravida woman presented to the outpatient department at 36 weeks gestation with violent abnormal movements of her upper limbs for past 4 days (video 1). The patient started having abnormal movements of her tongue which progressed to involve both of her arms in the time span of a day when she heard the news of her father's death. Her movements disappeared initially when she took some rest but they had become more violent since last 2 days so much so that she could not sleep. She had no antenatal health checkups during the pregnancy. The first and second trimesters of her pregnancy had been uneventful. At 3 weeks prior to her admission in our hospital, she had fever, sore throat and migrating polyarthralgia involving her left wrist followed by left knee joint. She reported history of similar episode of fever, sore throat followed by fleeting joint pains at the age of 15 years suggestive of an episode of rheumatic fever. There was no history of psychiatric illness. There was no history of any neuroleptic drug or metocloperamide intake.

On examination, the tongue was darting even at rest without patient being able to control it. She had bilateral choreoathetoid, purposeless, irregular, jerky movements in her upper limbs. On outstretching of the arms, there was hyperextension of the fingers with dorsiflexion of the wrist (spooning). Abdominal examination revealed uterine size corresponding to 34 weeks gestation with cephalic presentation. Biochemical investigations showed normal thyroid, liver and kidney function tests and throat swab culture was negative. Her serum tested negative for anti streptolysin O (ASO) titre, veneral disease research laboratory (VDRL), $\mathrm{C}$ reactive protein, lupus anticoagulant and antinuclear antibody. CT scan of the brain showed no abnormality.

\section{DISCUSSION}

Chorea is an involuntary abnormal movement characterised by abrupt, brief, non-rhythmic, nonrepetitive movement of any limb, often associated with non-patterned facial grimaces. The choreic movements may be caused by ischaemia or enhanced dopaminergic sensitivity mediated by increased female hormones during pregnancy. In recent times, most cases of chorea appearing during pregnancy in developed countries were caused by disease entities like systemic lupus erythematosus, Huntington's disease but rheumatic fever remains the cause in most of the developing countries. Some $35 \%$ of patients with chorea gravidarum have

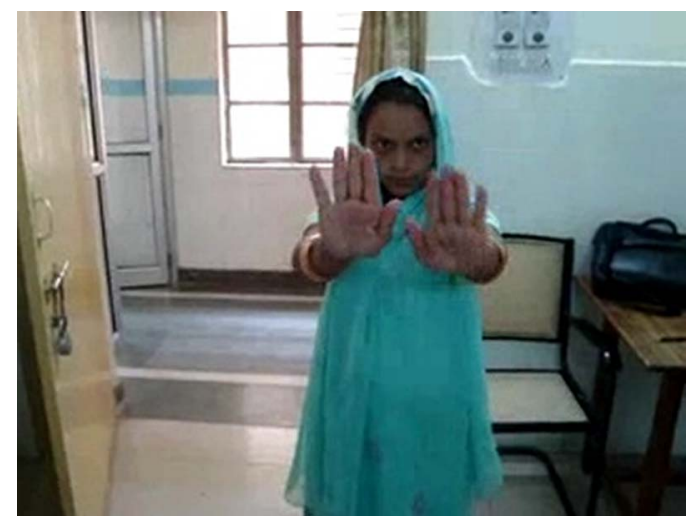

Video 1 Demonstration of choreic movements in a case of chorea gravidarum.

a definite history of rheumatism ${ }^{1}$ and as expected, this patient had a positive history suggestive of rheumatic fever at the age of 15 years. She did not take any treatment at that time because of her ignorance and reported to the hospital only when the home remedies have failed. She was administered one dose of longacting penicillin with multivitamins and multimineral therapy. This was accompanied by rest and seclusion and her chorea subsided with this treatment. This patient was diagnosed as chorea gravidarum secondary to rheumatic fever (most probable). Patients with Sydenham chorea are at risk for the development of rheumatic carditis particularly mitral stenosis and to prevent this, a regimen of daily penicillin prophylaxis should be instituted and maintained. ${ }^{2}$ Chorea in this patient did not affect her pregnancy and its outcome rather was helpful to the patient as she was started on penicillin prophylaxis which would prevent her from developing rheumatic heart disease in future.

\section{Learning points}

Pregnancy is the time of changing hormonal milieu, it can lower the threshold for chorea and emotional stress may precipitate it. ${ }^{3}$

- Mild choreic movements can be relieved by isolation, hydration and rest. Violent movements may put the life of the mother and the fetus in danger.

- Rheumatic chorea still haunts the pregnant women in the developing countries, though it is rare in the developed world.

\section{Competing interests None.}

Patient consent Obtained. 
Provenance and peer review Not commissioned; externally peer reviewed.

\section{REFERENCES}

1 Willson P, Preece AA. Chorea gravidarum. Arch Intern Med 1932;49:471-533, 671-697.
2 Johnston MV. Movement disorders. In: Kliegman S, St. Geme S, Behrman R, eds. Nelson textbook of pediatrics. 19th edn. Philadelphia: Elsevier Publisher,

2012:2053-8.

3 Balusamy SL, Rani R, Sagili H. A rare case of rhematic chorea probably unmasked by pregnancy. J Obstet Gynaecol 2010;30:29-40.

Copyright 2013 BMJ Publishing Group. All rights reserved. For permission to reuse any of this content visit

http://group.bmj.com/group/rights-licensing/permissions.

BMJ Case Report Fellows may re-use this article for personal use and teaching without any further permission.

Become a Fellow of BMJ Case Reports today and you can:

- Submit as many cases as you like

- Enjoy fast sympathetic peer review and rapid publication of accepted articles

- Access all the published articles

- Re-use any of the published material for personal use and teaching without further permission

For information on Institutional Fellowships contact consortiasales@bmjgroup.com

Visit casereports.bmj.com for more articles like this and to become a Fellow 